\title{
IMPOSTO SOBRE PROPRIEDADE: \\ UMA REFLEXÃO CRÍTICA DO CASO DO \\ Município de São Paulo e da Cidade de Nova Iorque \\ PROPERTY TAX:
}

a critical reflection on the cases of the Municipality of São Paulo and the City of New York

Luís Maurício Martins Borges

Universidade Estadual de Campinas, Instituto de Economia, Campinas, SP, Brasil.

R E S U M O : A questão central da investigação está em perceber as diferentes formas, relações e sistemas de imposto sobre a propriedade da terra urbana e a repercussão na organização política, econômica e social do Município de São Paulo (MSP) e da Cidade de Nova Iorque (NYC) entre 2000 e 2015. A partir das especificidades da execução da política fiscal, observam-se quais são os espaços, organizaçóes, coalizôes e interesses advindos das configuraçóes da dinâmica política e i mobiliária. Dessa forma, consideramos algumas instituiçôes, estratégias e movimentos interessados na produção e uso da propriedade imobiliária (moradia, direito à renda e valorização da riqueza), no bojo da política pública, fiscal e urbana das cidades. A investigação reflete sobre alguns dos determinantes da diferença fiscal do tributo sobre a propriedade da terra, no que diz respeito aos padróes de relação entre os agentes e instituiçôes que estabelecem específicas dinâmicas de produção, uso e apropriação do espaço social.

Palavras - Chave: Política; Pública; Fiscal; Urbana; Imobiliária; Propriedade; Renda.

A B S T R A C T: The central question of this investigation is to perceive the different forms, rela-tionships and systems of tax on the ownership of the urban land and the repercussions on the political, econo-mic and social organization of the Municipality of São Paulo (MSP) and of the City of New York (NYC) between 2000 and 2015. From the specificities of implementing fiscal policy, it is possible to observe the spaces, organizations, coalitions and interests that arise from the configuration of political and real estate dynamics. Thus, we consider some of the institutions, strategies and movements that are interested in the production and use of real estate (housing, right to income and wealth valorization), within the context of public, fiscal and urban policies for cities. The research reflects on some of the determinants of the fiscal differences between the taxation on land ownership, with regard to the relationship patterns between the agents and institutions that establish the specific dynamics of production, use and appropriation of social space.

KEYWORDS: Politics; Public; Supervisor; Urban; Real estate; Property; Income.

DOI: https://doi.org/10.22296/2317-1529.2018v20n3p570 


\section{INTRODUÇÃO}

A política urbana de uma cidade, entre outras dimensões, pode ser observada de uma forma bastante esclarecedora através de sua estrutura fiscal, que articula os interesses predominantes em diferentes estratégias de arrecadaçáo de impostos, relacionada à capacidade de despesa em infraestrutura, serviços públicos e sociais e associada às dinâmicas dos diversos setores econômicos privados. Com isso, há políticas e setores mais intimamente ligados por tributaçôes, legislaçôes, concessões e a açẫo direta do setor público, o que denota a relevância de se considerar qual a hierarquia específica do Estado que atua, regulamenta e se relaciona com o mercado, especialmente o imobiliário, quem dirige as coalizóes de interesses, como se financiam e se implementam as políticas públicas.

A convergência de interesses privados, de grupos com grande poder político e econômico, ganha força em relaçôes estratégicas existentes em torno de coalizóes de interesses em governos (em mandatos políticos - executivo, legislativo e cargos do judiciário), nas disputas por influência sobre arranjos específicos de poder, que convergem em regimes políticos ${ }^{1}$. Para o objetivo da presente investigação, destaca-se a predominância do regime de Crescimento, caracterizado por coalizóes públicas e privadas do tipo de máquina de crescimento imobiliário, inspirado na descrição de Molotch (1976), que, por meio do Imposto sobre Propriedade e de investimentos públicos, concessôes políticas e fiscais, promovem reconcentração de recursos e segregação das classes sociais, para finalidade de lucro e renda privada.

Por essa perspectiva, no início do século XXI, observamos a importância relativa do Imposto sobre a Propriedade de imóveis urbanos junto aos tributos próprios e transferências governamentais. Como nos EUA, no caso da NYC, é possível cobrar um Imposto sobre a Propriedade (ISP) mais elevado diante da realidade do Brasil, no caso do MSP? Para responder a essa pergunta utilizamos as informaçôes dos governos, mídias e censos.

Investigamos de que forma se opera a institucionalidade fiscal, como se legitima e se negocia a cobrança dos Impostos sobre a Propriedade, as coalizóes de interesses envolvidas e as estratégias de influência na direção da política fiscal. A partir das características, estratégias e usos do ISP como instrumento político e de planejamento do Estado, com destaque ao nível local, investigamos como o tributo se relaciona com os interesses da sociedade e com a forma de pressão de proprietários, produtores e incorporadores imobiliários, assim como com a resistência de movimentos por direitos sociais e civis na sua relaçáo com esse tributo, considerando as condiçóes de negociação, participação e de transparência.

\section{A ESTRUTURA DO IMPOSTO SOBRE PROPRIEDADE DA CIDADE DE NOVA IORQUE (NYC)}

O ISP, como tributo municipal da NYC, constitui-se na principal fonte própria de arrecadaçáo, tendo variado no período de 2002 e 2015, entre 20,5\% e 26,3\% da receita total. A Receita Total da NYC em 2015 constituiu-se de mais de US\$ 80 bilhōes, com importante contribuição do Imposto sobre a Propriedade (26,3\%),

1 Os tipos de regimes apontados por Stone (1993) podem apresentar as seguintes funções: i) manutenção de poder; ii) crescimento; iii) anticrescimento; e iv) assistência social. 
além de outros impostos (sobre Renda Pessoal 13\% e Vendas em Geral 8,4\%), que compóem as principais fontes das Receitas Próprias do Município (64,1\%). Além das receitas de transferências do estado de Nova Iorque $(15,6 \%)$ e do governo federal (10,5\%), que vêm caindo de participação desde antes de 2002 .

Tabela 1. As Receitas Reais* realizadas da NYC, corrigidas para o ano de 2015, segundo a contribuição do ISP, das Receitas Próprias e Totais, entre 2000 e 2015

\begin{tabular}{llllccccc}
\hline Arrecadação (em milhões US\$) & $\mathbf{2 0 0 2}$ & $\mathbf{2 0 0 5}$ & $\mathbf{\%}$ & $\mathbf{2 0 1 0}$ & $\mathbf{\%}$ & $\mathbf{2 0 1 5}$ & $\%$ \\
\hline Imposto sobre a Propriedade & 11.801 & $20,5 \%$ & 14.142 & $21,3 \%$ & 17.093 & $25,0 \%$ & 21.270 & $26,3 \%$ \\
Total de Tributos Próprios & 31.415 & $54,6 \%$ & 37.877 & $57,2 \%$ & 39.487 & $57,7 \%$ & 51.747 & $64,1 \%$ \\
Receita Total & 57.542 & $100 \%$ & 66.246 & $100 \%$ & 68.414 & $100 \%$ & 80.787 & $100 \%$ \\
\hline
\end{tabular}

Fonte: City Council/Adopted Budget/Fiscal Year 2000. 2015/Expense \& Revenue Contract. Elaboraçáo própria. * Dados atualizados para o nível de preços de 2015, através do Producer Price Index (PPI), $2010=100$. Disponível em: $<$ https://data.oecd.org/price/producer-price-indices-ppi. htm\#indicator-chart>. Acesso em jul. 2017.

2 Indica Bachur (2005, p. 381) que as competências administrativas do governo local nos Estados Unidos abrangem principalmente os serviços públicos de política, bombeiros, educação, infraestrutura urbana e viária.

3 Conforme dados verificados e disponíveis em: $<$ https://www.usgovernmentrevenue.com/>. Acesso em dez. 2017.

4 Como se vê no relatório ISP da Cidade de Nova lorque (Property Tax Annual Report, 2015, p. 25): "Quando o orçamento da cidade é adotado, são determinadas as despesas planejadas e as receitas previstas de todas as receitas que não sejam do ISP. A diferença entre essas magnitudes é valor do ISP necessário para o balanço do orçamento. Porque o ISP é o único instrumento sobre o qual a cidade tem prerrogativa de determinar a legislação sobre a taxa prioritária, inclusive com relação ao governo do estado". O trabalho de Di Pasquale e Wheaton $(1996$, p. 330) mostra como no país a determinação do ISP é definida a partir das despesas planejadas, deduzidas das transferências e da receita dos demais tributos, que define o valor do ISP, que sob uma razão do estoque imobiliário tributável, determina a alíquota tributada.
A despesa total decorrente dessa receita na NYC em 2015, em grande medida realizou-se em ao menos 8 grandes linhas programáticas-funcionais ${ }^{2}$, a saber: educação $(27,2 \%)$, serviço social $(17,8 \%)$, polícia, bombeiro e centros de correções $(10,1 \%)$, saúde $(2,2 \%)$, proteção ambiental (3,3\%), habitação a preço acessível (1\%), cultura e recreação $(1,2 \%)$ e transporte $(1,2 \%)$. Com essas linhas de políticas públicas concretizam-se uma boa parte da extensão de equipamentos, articulados por infraestrutura e serviços públicos e sociais estruturantes das condiçóes de produção e da vida na cidade. Mas os recursos disponíveis aos Departamentos (Secretarias) têm diminuído, com a sua concentração no gabinete do Prefeito.

Tabela 2. Distribuição Percentual da Despesa por Função de Governo, e o Total da Despesa Nominal, para valores de 2015, entre 2000 e 2015 na NYC

\begin{tabular}{lcccc}
\hline \multicolumn{1}{c}{ Total dos Departamentos (\%) } & $\mathbf{2 0 0 0}$ & $\mathbf{2 0 0 5}$ & $\mathbf{2 0 1 0}$ & $\mathbf{2 0 1 5}$ \\
\hline Educação & $29,0 \%$ & $27,0 \%$ & $30,2 \%$ & $27,2 \%$ \\
Serviço Social & $21,3 \%$ & $19,5 \%$ & $19,7 \%$ & $17,8 \%$ \\
Polícia, Bombeiro e Centro de Correções & $13,1 \%$ & $10,9 \%$ & $11,2 \%$ & $10,1 \%$ \\
Saúde & $6,9 \%$ & $6,5 \%$ & $4,7 \%$ & $2,2 \%$ \\
Proteção Ambiental & $1,6 \%$ & $1,4 \%$ & $2,3 \%$ & $3,3 \%$ \\
Habitaçao Social & $1,1 \%$ & $1,3 \%$ & $1,3 \%$ & $1,0 \%$ \\
Cultura e Recreação & $1,4 \%$ & $1,4 \%$ & $1,1 \%$ & $1,2 \%$ \\
Transporte & $0,6 \%$ & $0,5 \%$ & $0,6 \%$ & $1,2 \%$ \\
\hline Total de Recursos (em milhões de US\$) & $\mathbf{3 8 . 1 2 0}$ & $\mathbf{5 3 . 1 3 6}$ & $\mathbf{6 3 . 3 9 1}$ & $\mathbf{7 8 . 5 8 2}$ \\
\hline
\end{tabular}

Fonte: Disponível em: <http://www.ibo.nyc.ny.us/Fiscal History/Revenue \& Spendig since 1980/ Agency Expenditures. Acesso em Acesso em Jul. 2017.Elaboração própria.

Entre as características atuais da estrutura fiscal nos Estados Unidos, conforme os dados disponíveis do governo estadual e federal ${ }^{3}$, destaca-se a razoável distribuição da carga tributária entre os níveis de governo e a relevância da substância do ISP na receita local no conjunto do país. Além disso, o ISP destaca-se como instrumento de planejamento, determinado pela necessidade de despesa do governo local ${ }^{4}$, junto à sua capacidade política de se justificar na relação direta com a câmara legislativa, local e estadual e o eleitorado. Por conta disso, a progressiva reduçáo das transferências, desde o final do século XX, como se observa atualmente na Cidade de Nova Iorque, 
como mostrou a Tabela 1, tem tido a resposta da progressiva importância do ISP na contribuição à sua receita total.

\section{INSTITUCIONALIDADE LEGAL E ORGANIZACIONAL DO IMPOSTO}

O Imposto sobre a Propriedade (ISP) nos Estados Unidos tem o seu suporte principal na regulação estadual ${ }^{5}$, com relação aos diversos tributos, mas em especial sobre o Real Property Tax Law e Rules for Real Property Tax, que, junto às Legislaçóes da NYC, constituem as bases legais do sistema ${ }^{6}$. No nível estadual, define-se a proporção tributável do valor do imóvel para as quatro classes de usos (Tax Class: 1. residencial horizontal, até 3 unidades; 2. residencial vertical, mais de 3 unidades; 3. equipamentos públicos; e 4. outros usos). Em nível local, a NYC tem autonomia fiscal para definir alíquotas específicas sobre o uso dos imóveis e de negociar os limites estipulados pelo estado. A NYC é constituída por 5 regióes, boroughs ou distritos fiscais?: Manhattan, Brooklyn, Queens, Bronx e Staten Island.

O Prefeito inicia o processo com a proposta de orçamento, auxiliado pelo Office of Management and Budget (OMB), com a previsão de despesas e receitas para o ano vigente e os 3 anos subsequentes. A proposta é apresentada ao Legislativo Municipal, Agências e público em geral, em especial o Independent Budget Office (IBO), que pode contestar a avaliaçáo de preços e as alíquotas cobradas nas diferentes regióes da cidade. Depois, retorna ao executivo, que pode incorporar sugestóes e fazer o planejamento financeiro, seguindo em novas negociaçôes com o conselho municipal, até ser aprovado pelo legislativo.

O Department of Finance - DOF organiza e opera o sistema tributário local, encarregado da avaliação de preços, das especificidades das alíquotas, da metodologia do cálculo, isençôes e abatimentos, informando e esclarecendo a população sobre as fontes de arrecadaçôes. Especialmente no caso do ISP, o DOF oferece um relatório anual, prestando conta à sociedade, com diversos dados relevantes sobre a receita e dinâmica imobiliária.

O DOF disponibiliza cartilhas, em diferentes línguas para facilitar o acesso do contribuinte, a fim de explicar a cobrança dos impostos- Essas cartilhas visam a esclarecer sobre o método de apuração dos preços que, complementado pela informação do relatório anual, permite aos cidadãos uma visão abrangente do sistema de gestão do ISP, que se destaca dos demais tributos, inclusive com espaço para contestação, revisão e reparação das exigências.

Além da alíquota local da cidade, existe uma determinação da fatia tributável do preço do imóvel, definida pelo governo estadual, que constitui a taxa do ISP. Destaca-se a estratégia de regulação tributária de maior taxa de ISP para imóveis residenciais, especialmente os mais horizontais (classe 1, de 8,9\%), em comparaçâo aos mais verticais (classe 2, de 3\%). Há um maior alívio para equipamentos públicos (classe 3, de $0,4 \%$ ) e de outros usos (classe 4 , de $2,9 \%$ ). No ano de 2015, a Cartilha do ISP/DOF mostrava que a Classe de Uso 4 tinha a maior contribuiçáo total do ISP $(40,9 \%)$, seguida pelas classes $2(36,7 \%), 1$ $(15,5 \%)$ e $3(6,5 \%)$.
5 Di Pasquale e Wheaton (1996, p. 19) destacam que o Código de Imposto Federal é mais favorável aos proprietários, por conceder diferentes isenções e subsídios, enquanto em nível loca recebe uma taxação pesada.

6 Destaca Bachur (2005, p. 381) que a dinâmica política, jurídica e fiscal é minimamente definida pela constituição federal, com maior peso das constituições e tribunais estaduais, Suprema Corte e pelo costume e tradição.

7 Com informações específicas regionalizadas nos relatórios do ISP, além de representação de cada um dos boroughs. 
Tabela 3. As Taxas de Impostos sobre a Propriedade cobradas, constituídas por Alíquotas Locais da Cidade, e por limites tributáveis da Proporção do Preço do Imóvel, para as específicas Classes de Contribuintes (1, 2, 3 e 4), da NYC em 2015 e 2017

\begin{tabular}{lcccc}
\hline Classes de Imposto por Tipo de Uso em 2015 & $\mathbf{1}$ & $\mathbf{2}$ & $\mathbf{3}$ & $\mathbf{4}$ \\
\hline Proporção do Preço - Definição Estadual & $46,3 \%$ & $23,6 \%$ & $3,3 \%$ & $26,9 \%$ \\
Alíquotas Locais - Definição da Cidade & $19,2 \%$ & $12,9 \%$ & $11,1 \%$ & $10,7 \%$ \\
\hline Taxa de Imposto sobre a Propriedade & $\mathbf{8 , 9} \%$ & $\mathbf{3 , 0} \%$ & $\mathbf{0 , 4 \%}$ & $\mathbf{2 , 9 \%}$ \\
\hline Distribuição da Contribuição à Receita & $15,5 \%$ & $36,8 \%$ & $6,9 \%$ & $40,9 \%$ \\
\hline
\end{tabular}

Fonte: Residential Property Tax Guides, City of New York, 2015 e 2017. Disponível em: <http:// www1.nyc.gov/site/finance/taxes/property-reports.page>. Acesso em jul. 2017. Elaboração própria.

Com esse componente no cálculo do ISP, a classe 1 (imóveis com até 3 unidades), mesmo com a maior alíquota $(19,2 \%)$ e proporção $(46,3 \%)$ do preço tributável do imóvel, contribuía pouco $(15,5 \%)$ para a receita, pelo menor número desse tipo de imóvel. Já a classe 2 (residencial de mais de 3 unidades), com menor alíquota $(12,9 \%)$ e proporção tributável $(23,6 \%)$, constituiu uma maior contribuição ao ISP $(36,8 \%)$, devido ao seu mais elevado número. Há uma relação distinta na classe 3 (alíquota $11,1 \%$, proporção $3,3 \%$ e contribuição $6,9 \%$ ) de equipamentos públicos, em que se observa uma menor exigência contributiva. A classe 4 (alíquota 10,7\%, proporção $26,9 \%$ e contribuição $40,9 \%$ ) de imóveis comerciais, apesar da reduzida alíquota e moderada proporção do preço tributado do imóvel, constitui a maior contribuição, por conta da densidade dos imóveis, da escala do valor e do alcance internacional dos negócios na NYC, com o destaque de Manhattan.

Essa disponibilidade dos dados tributários, em tese, possibilita maior conhecimento e controle sobre o ISP e mercado imobiliário, tanto da cidade como da população interessada. Ainda, indica algumas características relevantes, como a maior concentração do valor dos imóveis de uso não residencial (Classe 4) em Manhattan (59,7\%), Queens (66,8\%) e em Staten Island (72,7\%), com valor de apartamentos mais concentrados em Manhattan (40\%), Brooklyn (36,2\%) e Bronx (35\%); de imóveis de até três unidades mais concentrados em Staten Island (20,4\%), Queens (9,1\%) e Brooklyn (7,4\%); e equipamentos públicos mais comuns no Queens (0,009\%), Manhattan (0,003\%) e Brooklyn (0,00001\%).

Os Relatórios do ISP observados por quinquênio entre 2000 e 2015 (Tabela 4), mostram que o número de contribuintes passou de mais de 928 mil para pouco mais de 1 milhão a partir de 2010, crescendo até 2015, com o incremento mais expressivo dos contribuintes de tributos completos (que chega a 48,5\% em 2015) e a redução dos contribuintes com desconto ( $48 \%$ em 2015), com pequeno aumento dos isentos e imunes (3,5\% em 2015). A proporção de tributo efetivamente arrecadado, com relação ao valor estimado do estoque imobiliário, caiu entre 2000 e 2010 de 2,60\% para $2,13 \%$, subindo para cerca de 2,35\% em 2015 . 
Tabela 4. Estrutura de Contribuintes da NYC, Tributados, com Desconto e Isentos, os Valores Reais reajustados* do Estoque Imobiliário Tributado e da Arrecadação de Imposto sobre a Propriedade, e o percentual Arrecadado com Relação aos Valores dos Estoques entre 2000 e 2015

\begin{tabular}{lcrrr}
\hline \multicolumn{1}{c}{$\begin{array}{c}\text { Propriedades } \\
\text { (Número) }\end{array}$} & $\mathbf{2 0 0 0}$ & $\mathbf{2 0 0 5}$ & $\mathbf{2 0 1 0}$ & \multicolumn{1}{c}{$\mathbf{2 0 1 5}$} \\
\cline { 2 - 5 } & 928.570 & 988.561 & 1.059 .055 & 1.092 .453 \\
\hline Tributo Completo & & 416.532 & 422.770 & 529.985 \\
Tributo com Desconto & 536.219 & 599.065 & 524.397 \\
Isenção e Imunidade & 35.810 & 37.220 & 38.071 \\
\hline Valor do Estoque Imobiliário Tributado & $\mathbf{4 5 4 . 5 1 2}$ & $\mathbf{6 6 4 . 7 9 8}$ & $\mathbf{8 4 1 . 8 0 5}$ & $\mathbf{9 0 6 . 2 7 4}$ \\
Total da Cidade (US\$ milhões) & 11.801 & 14.142 & 17.093 & 21.270 \\
\hline Imposto sobre Propriedade Arrecadado & $2,60 \%$ & $2,13 \%$ & $2,03 \%$ & $2,35 \%$ \\
\hline Imposto sobre Propriedade/Estoque Imobiliário & & &
\end{tabular}

Fonte: Property Annual Report 2015/Fast Facts for FY 2000, 2005, 2010 e 2015. Elaboraçáo própria. * Dados atualizados para o nível de preços de 2015, através do Producer Price Index (PPI), $2010=100$. Disponível em: <https://data.oecd.org/price/producer-price-indices-ppi.htm\#indicator-chart>. Acesso em abr. 2018.

O valor total do estoque de imóveis tributados avaliados em 2015 era de cerca de US\$ 906 bilhôes, dos pouco mais de 1 milhão de propriedades, com preço médio de US\$ 900 mil. O Valor Tributado Avaliado Total da NYC distribuía-se: entre as classes de impostos majoritariamente na classe $4(62,7 \%)$, depois da classe $2(32,9 \%)$, classe $1(6,1 \%)$ e classe $3(0,0004 \%)$; e por boroughs, com valor mais concentrado em Manhattan (58,8\% e preço médio da propriedade US\$ $2.951 \mathrm{mil})$, Queens (17\% e US\$ 696,3 mil), Brooklyn (14,4\% e US\$ 754,1 mil), Bronx (6,9\% e US\$ 693,7 mil) e Staten Island (2,9\% e US\$ 480,5 mil).

Esse tipo de dado sobre a avaliaçáo dos imóveis, com a sua descriçáo de localização física, junto à classe de uso, alíquotas e isenção ${ }^{8}$, permite considerar não só o enquadramento e a contribuição, nos diferentes níveis de vizinhança, como recorrer via IBO e DOF, em uma contestação, justificativa e, se for o caso, revisão do imposto cobrado. Isto garante um alto grau de transparência ao sistema, ainda que as negociaçôes por isençáo possam ocorrer nos bastidores, no gabinete do prefeito e de oficiais, mas que podem ser mais facilmente explicitadas pela curiosidade da sociedade civil, pela ampla publicação de informaçóes.

Como se observa nos Relatórios Anuais das Propriedades (PAR, 2000/2015), a institucionalidade do sistema do ISP na NYC mostra-se bastante estruturada, já desde o início dos anos 1980, quando implementam-se mudanças pontuais e estratégicas em favor do mercado, com relação às classes de incidência, usos, valor tributável e as especificidades dos imóveis. Até a primeira década do novo século, essas mudanças advieram fortemente influenciadas pela estratégia de estímulo ao mercado por meio da isenção do ISP. No período mais recente, delineia-se uma estratégia de menor tributação relativa de imóveis apartamento (Classe 2), equipamentos (Classe 3) e outros usos (Classe 4), na direção de maior oneração de imóveis menos densos (Classe 1) em termos de unidades, ainda que com uma menor participação, se comparada à contribuição de imóveis mais densos e de atividades de negócios? .

Além dessa estratégia de tributação, o sistema é marcado pela transparência, observada por meio dos relatórios do ISP, Cartilhas e dados disponíveis em vários anos, da ampla base de propriedades. Isso possibilita a prestação de contas, inclusive com detalhamento dos usos e atividades dos imóveis, além da sua contribuição e a isençấo indicada no conjunto de regiôes da cidade. Além disso, a avaliaçấo dos preços
8 A distribuição da isenção parcial e total do ISP, no conjunto da NYC, alcançava cerca de US\$ 124 bilhões do estoque total $(13,7 \%)$, concentrados na Classe 4 $(77,2 \%)$ e na Classe $2(20,1 \%)$ Elas eram menores na Classe $1(1,7 \%)$. Não surpreende a concentração das isenções em Manhattan (72,5\%), sucedida pela do Queens (23,5\%), Brooklyn $(19,1 \%)$ e Bronx (10,5\%).

\footnotetext{
9 Como nos diz Zukin (2010, Pg. 1 e 2 - tradução nossa): Uma singularidade de Nova Iorque, com relação a Paris e Londres, é a retórica de escala de crescimentos (verticalização - "Manhattanization" significa em qualquer lugar do mundo, arranha-céus).
} 
10 Logan e Molotch (1987, p. 3 ; 121) destacam a capacidade norte-americana de manipular as condições de vida por meio da valorização dos preços de imóveis e lugares. Entre o centro da metrópole e os subúrbios, até pela fuga da decadência de áreas, busca-se atrair pessoas afluentes, com linhas de produtos $e$ influência dos produtores imobiliários sobre a política urbana.

110 que inclusive altera a estrutura tributária relacionada à propriedade, na direção da isenção (MOODY 2007, P. 287).
12 Ver em: A tax break that is a boon to housing (02/02/2015). é baseada no registro de vendas, apuradas por classe e localização do imóvel; mas, por náo determinar a receita arrecadada, que se origina de fato da necessidade de despesa pública, minora o conflito político sobre a avaliação dos preços dos imóveis para a finalidade de tributação. O conflito de resistência a contribuição fiscal se localiza na definição das taxas de alíquotas, de valores tributáveis e das isençôes, negociadas e aplicadas pela cidade e estado.

\section{Associações de Interesses Sociais e de Negócios, NA Política FISCAL}

Uma peculiaridade da NYC está na condição das propriedades em ilhas e faixas de terras litorâneas, inclusive do denso território ao longo da Metrópole ${ }^{10}$. A produçáo de valor nessa macrorregiáo, em muitas centenas de bilhóes de dólares, permitiu a um diverso grupo de empresas transformar-se em corporaçóes, cravando os nomes dos clãs que construíram pequenos impérios, nos enormes prédios de Manhattan: Durst, Helmsley, Spear, LeFrank, Levitt, Milstein, Rose, Starret, Tishman-Speye, Trump e Zeckendorf; junto a Fundos de Investimento e Patrimoniais e corporaçóes imobiliárias gigantes, com megaprojetos em muitas cidades, com papel crescente em Nova Iorque, como Vornando Realty Trust, Forest City Ratner e The Related Group (ANGOTTI, 2008, p. 38). A estrutura do mercado imobiliário de clás, fundos e corporaçôes também inclui milhares de pequenos e médios proprietários, nas cinco regiōes administrativas ou boroughs (distritos) da cidade.

A dinâmica da produção imobiliária na NYC constituiu, ao longo do século $\mathrm{XX}$, um bloco de interesses econômicos e institucionais orientados ao permanente crescimento imobiliário, expansão de equipamentos, dos serviços públicos e sociais ${ }^{11}$. Esse movimento sob a liderança do Real State Board of New York (REBNY) e do NYC Partnership, articula interesses dos grupos de corporaçóes da produção imobiliária, do setor financeiro e da comunidade de negócios em geral. A atuação do REBNY reúne a elite imobiliária e financeira, junto à Parceria da NYC, de interesses comerciais e industriais, orientados à constituição de condiçôes para valorização (inflação) dos preços dos imóveis, de Manhattan até os demais condados.

A Parceria da NYC, como organizaçáo "sem fim lucrativo", forma-se por um grupo de seletos diretores executivos, cujas companhias representam o emprego de 1,5 milhão de nova-iorquinos. A entidade origina-se da fusão, em 2002, da Câmara de Comércio e Indústria de Nova Iorque e a Parceria de Nova Iorque, fundadas, respectivamente, em 1768 e 1979, para defender os interesses econômicos nos cinco distritos.

O REBNY, fundado em 1896, organiza-se por meio de diversas comissóes, cujos membros tratam de temas como: Política Tributária, Transporte, Propriedades, Administração e Gestão do Desenvolvimento, Legislação etc. A entidade age desde antes dos programas de renovação urbana e de bem-estar social, dos anos 1930 a 1970, até a instauração da máquina de crescimento imobiliário, em meados dos 1970. Negocia com diferentes setores do governo, dentro do sistema institucional de ISP, para que os incentivos sejam dados para a promoção de novos ou recuperação de antigos imóveis. A entidade também representa a "voz" dos empresários sobre impostos, questóes regulatórias e legais para elevar a posição "competitiva e o crescimento da cidade". Tal como a isenção 421a do ISP, como incentivo ao construtor, solicitada pelo presidente do REBNY em artigo no The New York Times ${ }^{12}$. 
Entre as prioridades da entidade está a solicitação de menores impostos para o desenvolvimento de negócios mais competitivos, ou seja, o lobby para a redução do ISP da Classe 2 e 4 . Argumenta, em sua página na internet, que as despesas imobiliárias e tributárias tornam o custo de realização dos negócios relativamente elevado na cidade, acima dos demais centros do país ${ }^{13}$. Os interesses da entidade concentram-se nos setores financeiro, comerciais, tecnologia, informação e informática, entre outros.

As organizaçôes de interesses de empresários da produção imobiliária, proprietários e setor financeiro, seja o REBNY ou a Parceria, constituem uma clara forma de pressão e defesa de interesse na "valorização" da propriedade, entre outros meios, através do sistema de ISP, que se organiza nas últimas décadas do século XX, com forte influência sobre a política fiscal local, nos mandatos Bloomberg e Giuliani. Observa Angotti (2008, p. 40-41, tradução nossa):

...] investidores representativos do mercado imobiliário, por meio de fundos de investimentos imobiliários (Real Estate Investment Trusts - REITs) juntaram bancos, companhias de seguros e de corretagem a fim de elevar a capacidade dessa indústria, na condição de organização monopolista/oligopolista de capital.

O presente governo do prefeito Bill de Blasio afastou-se da prática estrita de crescimento imobiliário, sob a influência direta das finanças, em direção ao desenvolvimento socioeconômico destinado à melhoria das condiçôes das classes média $\mathrm{e}$ baixa, com maior participação do ISP, como verificado nas Tabelas 1 e 4. Isso não significou o seu afastamento completo do setor da construçáo, pelo apego à necessidade de intensa produção residencial, simbolicamente dirigida às classes média e baixa, mas em substituição às áreas públicas disponíveis na cidade, que servem como parques, jardins e espaços de lazer, e com alto potencial de gentrificação das vizinhanças pobres, negras e latinas ${ }^{14}$.

A NYC tem tido um longo histórico de lutas sociais, organizadas em bases comunitárias e em movimentos de luta por moradia, controle de aluguéis, contra expulsôes, segregação e gentrificação, que acompanham o desenvolvimento histórico da cidade. Contra esse tipo de projeto, além das comunidades de bairros, que atuam desde o fim do século XIX, algumas organizaçóes têm proposto novas formas de organização da política pública e até da iniciativa de produção, financiamento e propriedade imobiliária. Destacam-se a Real Estate Investment Cooperative (REIC), criada em 2015 como a estratégia de cross-funding para a compra de terra para áreas comuns, jardins, práticas cooperativas, culturais e habitação a preços acessíveis, e a New York Community Land Initiative (NYCLI), atuando desde 2012, com a finalidade de promoção de confiança em nível comunitário e a busca do apoio da política pública, para a manutenção da população de baixa renda na cidade.

A política de isenção fiscal ao setor da construção na NYC, que promove a elevação da rentabilidade do negócio, possui registro histórico do seu impacto sobre a redução da receita, da despesa pública e da distribuição da riqueza. Além da substância do ISP, o que chama a atenção é a elevada disposição relativa de informação sobre o mercado, como base para o planejamento da despesa, que possibilita maior conhecimento, debate e controle social sobre o uso e especulação do preço de imóveis, por parte de proprietários, moradores e movimentos organizados. Uma evidência dessa condição é a baixa participação dos terrenos no conjunto de propriedades, pela
13 Ver em: New York's Future as the World Financial Capital, 2015, p. 24. 
característica intensidade de uso da terra, o que pressiona a disputa recente pelas áreas existentes e os usos possíveis e desejáveis dos espaços da NYC, e que passa pela discussão, decisão e prática da estratégia do ISP na cidade.

\section{A ESTRUTURA DO IPTU DO MUNICÍPIO DE SÃO PAULO (MSP)}

A Receita Tributária Municipal própria é composta por Taxas, Contribuiçôes (por melhorias) e impostos como IPTU, ITBI (Imposto sob as Transferências de Bens Imobiliárias) e ISS (Imposto Sobre Serviços), além da menor participação no IPVA (Imposto sobre a Propriedade de Veículos Automotores, transferido pelo estado) e IRRF (Imposto de Renda Retido na Fonte). Em 2015, enquanto o IPTU representava $13,6 \%$, da receita total (corrente líquida) de mais de 48 bilhóes, o ISS era de $25,2 \%$, a receita própria constituía $58 \%$ do total arrecadado, e as transferências do estado eram de 19,3\%, e federal, de $12 \%$. Entre 2000 e 2015, ainda que o dinamismo imobiliário tenha sido bastante elevado, a participação do IPTU reduziu-se progressivamente de $16,8 \%$ para $13,5 \%$ no conjunto das receitas totais, até se recuperar um pouco recentemente (13,6\% em 2015), quando foi possível o reajuste da base de preços imobiliários sobre o qual se calculava o imposto.

Tabela 5. A arrecadação do Município de São Paulo (MSP), considerando o IPTU, as Receitas Próprias e Totais Reais*, entre 2000 e 2015

\begin{tabular}{|c|c|c|c|c|c|c|c|c|}
\hline $\begin{array}{c}\text { Arrecadação (em } \\
\text { milhões reais de 2015) }\end{array}$ & 2000 & $\%$ & 2005 & $\%$ & 2010 & $\%$ & 2015 & $\%$ \\
\hline IPTU & 4.160 & $16,8 \%$ & 4.129 & $15,6 \%$ & 5.568 & $13,5 \%$ & 6.543 & $13,6 \%$ \\
\hline Receita Própria & 10.451 & $42,2 \%$ & 12.725 & $48,1 \%$ & 26.494 & $64,3 \%$ & 27.901 & $58,0 \%$ \\
\hline Receitas Total & 24.782 & $100 \%$ & 26.463 & $100 \%$ & 41.203 & $100 \%$ & 48.102 & $100 \%$ \\
\hline
\end{tabular}

Fonte: PMSP/Fazenda/Contas Públicas/Receitas Arrecadas (2005 a 2015). Disponível em: $<$ http://www.prefeitura.sp.gov.br/cidade/secretarias/fazenda/contaspublicas/index.php? $\mathrm{p}=3216>$. Acesso em jan. 2018. Receitas Arrecadadas (2000), F. Seade e Demonstrativos Gerais do Município PMSP, 2015. Elaboração própria. * Reajustado pelo IGP-DI, disponível no Ipeadata, ao nível de preço de 2015.

São com essas Receitas Totais que se realizam a despesa municipal de São Paulo, em grande medida, por meio de 9 grandes linhas programáticas-funcionais ${ }^{15}$, que tinham a seguinte distribuição em 2015: educação (19,3\%), saúde (18\%), urbanismo $(9,7 \%)$, transporte $(8,5 \%)$, habitação $(4,5 \%)$, assistência social $(2,3 \%)$, saneamento $(2,3 \%)$, cultura, desportes e lazer $(2,4 \%)$ e gestão ambiental ( $0,6 \%)$. Com isso, organiza-se a agenda dos equipamentos estruturantes das condiçôes de produção na cidade, com infraestrutura e serviços públicos e sociais, que deveria ajudar a integração da população ao mercado e especialmente aos direitos. 
Tabela 6. Despesa por Função e Funçôes Agrupadas do MSP entre 2002 e 2015

\begin{tabular}{lcccc}
\hline \multicolumn{1}{c}{ Despesas por Função } & $\mathbf{2 0 0 2}$ & $\mathbf{2 0 0 5}$ & $\mathbf{2 0 1 0}$ & $\mathbf{2 0 1 5}$ \\
\hline Educação & $24,6 \%$ & $25,8 \%$ & $24,7 \%$ & $19,3 \%$ \\
Saúde & $17,8 \%$ & $20,9 \%$ & $20,7 \%$ & $18,0 \%$ \\
Urbanismo & $12,8 \%$ & $13,0 \%$ & $10,1 \%$ & $9,7 \%$ \\
Transporte & $6,6 \%$ & $6,5 \%$ & $9,6 \%$ & $8,5 \%$ \\
Habitação & $2,0 \%$ & $0,8 \%$ & $3,8 \%$ & $4,5 \%$ \\
Assistência Social & $1,9 \%$ & $1,3 \%$ & $2,8 \%$ & $2,3 \%$ \\
Saneamento & $2,4 \%$ & $0,6 \%$ & $1,4 \%$ & $2,3 \%$ \\
Cultura, Desporto e Lazer & $2,5 \%$ & $1,5 \%$ & $2,3 \%$ & $2,4 \%$ \\
Gestão Ambiental & $0,7 \%$ & $0,7 \%$ & $1,0 \%$ & $0,6 \%$ \\
\hline Total de Despesas Municipais & $\mathbf{2 0 . 0 4 4}$ & $\mathbf{2 1 . 1 2 3}$ & $\mathbf{3 2 . 3 1 9}$ & $\mathbf{5 1 . 3 3 3}$ \\
(em milhões de R\$) & \multicolumn{3}{|c}{} \\
\hline
\end{tabular}

Fonte: Secretaria Municipal da Fazenda Orçamento Executado e Pago. Disponível em: <http:// orcamento.sf.prefeitura.sp.gov.br/orcamento/execucao.php >. Acesso em jan. 2018. Elaboração própria.

Destacamos que a construção da autonomia fiscal possível do MSP, com a redução do suporte federativo intergovernamental, tem-se marcado pela expansão do ISS, assim como de outras receitas, com uma menor contribuição relativa do IPTU, que tem crescido pouco em termos absolutos e relativos ao conjunto da receita tributária e total, em um momento de pujante "valorização" dos preços das propriedades imobiliárias. A novidade tem sido a abertura dos dados cadastrais utilizados pelo IPTU, o que possibilita um primeiro retrato, com uma lente estrutural da distribuição das propriedades por conjuntos regionais e da cidade. Se náo representa a plena realidade, o registro do Cadastro Imobiliário Fiscal (CIF, 2016) é importante por mostrar-se como o meio pelo qual o governo local atua, decide e intervém, na condução das políticas públicas, fiscal, urbana e patrimonial no MSP, denotando também a dificuldade de sua institucionalização e efetivação da sua capacidade arrecadatória.

\section{INSTITUCIONALIDADE LEGAL E ORGANIZACIONAL DO IMPOSTO}

O sistema de Imposto Predial e Territorial Urbano (IPTU), no Brasil, tem profundas amarras institucionais, legais e administrativas, principalmente a partir do nível federal do Estado, complementadas pelo nível municipal, que instituem e regulamentam as bases do planejamento do setor público, que estrutura o sistema fiscal de forma regressiva ${ }^{16}$. A partir da Constituição Federal de 1988, acentuou-se a centralização da receita no nível federal, em paralelo à maior distribuição das atribuiçôes e encargos na direçâo dos municípios, ou seja, da responsabilidade da gestão da despesa pública dos serviços públicos diretos aos cidadãos, com algum aumento de transferências intergovernamentais, mas que, com o tempo, voltaram a se concentrar no nível federa ${ }^{17}$, tanto nas receitas como nas decisóes de investimento. Dessa forma, o sistema é baseado na previsão, programação e arrecadação dos recursos próprios, das transferências dos demais níveis de governo e controle das despesas públicas por períodos de quatro anos de horizonte de planejamento.

O sistema tributário do MSP (Lei municipal n. 6.989/1966) constitui a base da atual institucionalidade do IPTU, articulando a política de arrecadação entre seus componentes fundamentais, que determinam o cálculo da contribuição anual. Essa 
18 Cano (2011, p. 45 e 108$)$ lembra a histórica falta de diálogo, consulta e participação da cidadania caracterizada pela postura autoritária do Estado, com relação à evolução fiscal, assim como à forte influência privada sobre a despesa pública, que possibilita a especulação de imóveis, em áreas próximas de infraestrutura e serviços públicos sob baixo nível de contribuição fiscal.

19 Esse uso do IPTU é chamado de Parcelamento, Edificação e Utilização Compulsórios, esclarecido em: "http://gestaourbana.prefeitura.sp.gov. $\mathrm{br} / 20$-perguntas-e-respostas-sobre-parcelamento-edificacao-e-utilizacaocompulsorios-peuc/". lei, subordinada ao Código Tributário Nacional (CTN, 1966), define os limites das áreas urbanas pela existência de melhoramentos executados pelo poder público. Conforme essas referências legais, são estabelecidos os critérios de contribuição, imunidades e isenções, as exigências e punições.

A partir do sistema tributário, novos aspectos institucionais seriam desenvolvidos nas décadas posteriores, constituindo um sistema fortemente regido por leis. Além disso, outras características relativas ao processo de urbanização, como o rápido crescimento econômico e demográfico no século XX, assim como o severo controle político e militar até os anos 1980, marcariam a fraca institucionalização administrativa, de procedimentos e de prestação de contas à sociedade, de disposição de informação pública, como também da participação e negociação fiscal, referente tanto à despesa como à arrecadaçăo ${ }^{18}$. Com isso, a política fiscal acirraria os conflitos pela terra, vedando o acesso a direitos sociais, pela resistência à incorporaçáo do mercado "informal" (em favelas, cortiços, pensóes e outras formas de moradia precária, como loteamentos precários periféricos) no CIF do MSP.

A trajetória institucional-histórica posterior do IPTU tomaria um curso singular por meio da lei de 1986 (Lei municipal n. 10.235), de forma a detalhar extensamente as características tipificadas e materiais, a fim de se enquadrar além das dezenas de classes de tipos de usos, outras dezenas de tipos de padrôes de construção, utilizados para a determinação do preço do imóvel e da cobrança do imposto. A Lei do MSP de 1986 gerou o enquadramento por tipos e subtipos de imóveis residenciais e não residenciais, considerando ainda a área físico-espacial do terreno, o padrão e a área de construção, a idade e outros detalhes como meio de determinação ou de aproximação do preço do Valor Venal do Imóvel (VVI).

Outra inovação adviria com a Lei municipal n. 13.250/2001, que diferencia os descontos e acréscimos das alíquotas base de tributos, residencial e não residencial, constituindo uma forma de progressividade da contribuição por faixas de VVI. A diferenciação de alíquotas básicas de IPTU relaciona-se a dois usos específicos de imóveis: no caso de residenciais, a alíquota é de $1 \%$ sobre o VVI; no caso de não residenciais - referentes a outros usos como terrenos, indústria, comércio, serviços e outros -, a alíquota é de 1,5\% sobre o VVI. Mais recentemente, tem havido a regulamentação de instrumentos para cumprimento da função social da propriedade, como de progressividade do IPTU em caso de imóveis subutilizados, mas ainda sem grande continuidade da política, portanto, impacto ou repercussão ${ }^{19}$.

Pela forma legal de organização do sistema tributário do MSP, que dispensa o uso de relatórios sobre a realização e prestação de contas do imposto, torna-se complexa a apuração da alíquota do IPTU. A alíquota do imposto para uso residencial varia por lei entre $0,7 \%$ e $1,5 \%$, em função dos Decréscimos e Acréscimos e por faixa de VVI. No caso de uso comercial, industrial, serviços e terrenos considerados não construídos, a alíquota de imposto também pode variar de 1,1\% a 1,9\%, por conta de Decréscimos e Acréscimos, conforme o VVI.

O sistema é organizado a partir do fato gerador do tributo pelo domínio ou posse de imóvel; para o qual se faz o cálculo da Planta Genérica de Valores (PGV) e do Valor Venal do Imóvel (VVI), considerando em detalhes as especificidades de padrōes construtivos e tipológicos de usos dos imóveis. Sobre o VVI incide a alíquota, diferenciada por uso residencial ou não residencial, com acréscimo e decréscimo e descontos do valor tributado, tudo por faixas de VVI. Com base nessa estrutura, 
realiza-se a arrecadação do IPTU, ligado à Secretaria de Finanças e Desenvolvimento Econômico (SMFDE), atualmente, da Fazenda (SMF).

O Valor Venal do Imóvel (VVI) resulta da soma do Valor Venal do Terreno (vvt), considerando a sua área e Fração Ideal (F/Id), com o Valor Venal da Construção (vvc), por tipo, padrão, área e regiáo, relacionado ao Fator de Obsolescência (FObs). O VVI define os Descontos e Acréscimos à Alíquota Tributada, além da Isenção do vvc, e dos Diversos Descontos (DIV) sobre o VVI tributável (conforme Artigo 16 da CLT do MSP, 2015).

Tabela 7. Fórmula de Cálculo do IPTU no Município de São Paulo, constituída por Alíquota, Valor Venal do Imóvel (VVI) e Diversos Descontos ${ }^{(* *}$ ) e Isençôes (**)

\begin{tabular}{|c|}
\hline Receita do Tributo = Alíquota $\cdot\left(\mathrm{VVI}^{*}-\mathrm{DIV}^{* *} \mathrm{e}^{* * *}\right)$ \\
\hline Alíquota $=$ Desconto + Acréscimo $=>$ f.(VVI) \\
\hline $\mathrm{VVI}^{*}=((\mathrm{vvt}$. Area $) \cdot \mathrm{F} / \mathrm{Id})+((\mathrm{vvc} \cdot$ Area).FObs $))$ \\
\hline DIV = Desconto** e Isenção*** do VVI => f(VVI) \\
\hline
\end{tabular}

Fonte: Elaborado pelo autor, com base na Consolidaçâo das Leis Tributárias de 2015 (CLT, 2015). * O Valor Venal do Imóvel (VVI). ${ }^{* *}$ Os descontos referem-se ao valor predial de imóveis não residenciais até $R \$ 90$ mil, residenciais até $R$ \$ 160 mil e por faixas de valor até $R$ \$ 180 mil e até R\$ 320 mil, com desconto sobre o valor do imóvel tributado. *** As imunidades e isençóes consideradas referem-se à propriedade dos 3 níveis de governo, usadas como templo e patrimônio histórico, cultural e ambiental.

Um aspecto a se considerar, pela diferenciação das alíquotas em uso residencial (1\% do VVI) e não residencial (1,5\% do VVI) de imóveis, é o impacto dessas diferenças sobre os conjuntos de contribuintes, os valores de estoque imobiliários tributados e as contribuiçôes. Isso porque o conjunto de imóveis residenciais, em todo o período, tem sido a proporção majoritária dos imóveis inscritos no CIF, cerca de 84,6\% em 2015. Os conjuntos não residenciais representam somente $15,4 \%$ do conjunto total. Entretanto, o valor dos imóveis não residenciais tem maior participação relativa no valor do estoque, com $38,7 \%$, enquanto o uso residencial representa $61,3 \%$ do conjunto do estoque imobiliário. As contribuiçôes ao IPTU dos respectivos usos eram ainda mais importantes na direção dos imóveis não residenciais, que representava 50,4\%, em 2015, com relação à contribuição dos imóveis residenciais, de 49,6\%, tanto pela diferença de preço avaliado como das diferentes alíquotas por usos.

Nos conjuntos de usos residenciais, dois apresentam maior importância em sua magnitude de contribuintes. Os apartamentos residenciais, cerca de $37,2 \%$ do total do MSP, mais concentrados nas regiôes Oeste (23,6\%), Sul 1 (14,5\%) e Centro $(15,3 \%)$. E as residências horizontais, que representam $34,7 \%$ do total, e se destacam nas regióes Leste 2 (21,7\%), Sul 2 (18,5\%) e Norte 2 (12,4\%). As residências coletivas constituíam 6,2\% do total de usos das propriedades do MSP, mais concentradas nas regiōes Leste 2 (22,1\%), Leste 1 (20,7\%), Sul 2 (18,3\%), Norte 2 (14,3\%) e Norte 1 (11\%). Os cortiços, reconhecidos pelas inscriçôes de usos dos imóveis no CIF, têm uma distribuição bastante homogênea nas regiōes do MSP, com alguma concentração nas regiōes Leste 1 (21,6\%), Leste 2 (15,3\%) e Norte 1 (13,3\%).

O conjunto de imóveis de uso náo residencial representava, em 2015, cerca de $22,6 \%$ do conjunto geral de propriedades do MSP, que se forma principalmente por escritórios, lojas e outras edificações $(9,8 \%)$, garagens $(7 \%)$, por terrenos $(3,4 \%)$, por 
20 A análise dos terrenos do CIF 2016, nos quatro cantos do MSP, considerando as menores contribuições ao IPTU (até R\$ 10,00 por propriedade), mostra o contraste importante entre as grandes áreas $\left(\mathrm{m}^{2}\right)$ e os respectivos proprietários fundiários beneficiados pela subavaliação do IPTU: i) região Leste 2 a Noruega Empreendimentos Imobiliários Ltda. destaca-se pela propriedade de 18 terrenos, de mais de $315,4 \mathrm{mil} \mathrm{m}^{2}$, avaliados em $\mathrm{R} \$ 13 \mathrm{mil} \mathrm{e}$ contribuição ao IPTU de R\$ 147,11; na região Oeste a Jaguaré Patrimonial Ltda. com 26 propriedades, mais de $173,3 \mathrm{mil} \mathrm{m}^{2}$, avaliados em $\mathrm{R} \$ \mathrm{R} \$$ 10,1 mil e com contribuição de R\$ 111,17; na região Norte 2 a Norozar Empreendimentos Imobiliários Ltda. com duas propriedades de 3,6 mil $\mathrm{m}^{2}$, avaliados em $\mathrm{R} \$$ 1,3 $\mathrm{mil}$, paga ao imposto $\mathrm{R} \$ 14,14$; e na região Sul 2 da Marques Construtora e Incorporadora Ltda. com 9 propriedades, mais de 3,1 mil $\mathrm{m}^{2}$, avaliados em $\mathrm{R} \$$ 7,5 mil, que pagavam apenas $\mathrm{R} \$ 83,26$ de tributos ao município.

21 A região Sul 2, em uma das suas subprefeituras, tem sido afetada pelo crescimento do mercado imobiliário formal, em meio a predominante condição de pobreza e informalidade das demais subprefeituras da região, subamostradas no CIF.

22 As informações sobre a situação de Imunidade, Isenção total e parcial foram disponibilizadas pela Secretaria Municipal das Finanças (SMF), mediante a Lei de Acesso a Informação (Lei n. 12.527/2011), pelo pedido e-SIC n. 28063/28066 de $19 / 01 / 18$. As imunidades, isenções totais e parciais abrangiam $18,7 \%$ do VVI do CIF em 2015 (5,7\% imunes, $2,1 \%$ isentas totais e $10,9 \%$ parciais). Elas distribuíamse em residenciais $(45,9 \%)$ e outros usos (54,1\%). Elas concentram as Imunidades e isenções totais nas regiões Oeste, Leste 1 , Sul 1 e Centro, e as isenções parciais nas regiões Leste 1 e 2, Norte 2, Leste 2 e Sul 2. sua vez, os demais usos eram menos frequentes. Os imóveis de uso do tipo escritórios, lojas e outras edificaçôes e as garagens estáo principalmente nas regiôes Oeste (25,9\% e 35,2\%), Centro (23,3\% e 23,3\%), Leste 1 (13,9\% e 11,1\%) e Sul 1 (12,2\% e 13,9\%). Hospitais, escolas, hotéis, flats, cinemas, teatros etc. também se concentram nas regióes Oeste, Centro, Leste 1 e Sul 1. Nas regiōes Sul 2, Norte 2 e Leste 2, concentram-se os terrenos ${ }^{20}$ e os templos, além de uma porção relativamente menor de imóveis ligados às diversas atividades econômicas e sociais.

As regiōes administrativas podem ser apresentadas também por meio da relação da distribuição dos valores e da hierarquia dos preços médios dos imóveis avaliados. As regiôes mais centrais apresentavam maior concentração de valor do MSP e elevação dos preços médios, como Centro (10,6\% do valor do estoque imobiliário e preço médio de R\$ R \$ 381 mil), Oeste (28,5\% e R \$ 556 mil), Leste 1 (6,3\% e R \$ 305 mil), Norte 1 (8,2\% e R 297 mil) Sul 1 (5,5\% e R \$ 372 mil). Enquanto as regióes mais periféricas, como Leste 2 ( $4,8 \%$ e R \$ 125 mil), Norte 2 (11,7\% e R 232 mil) e Sul 2 ( $19 \%$ e $\mathrm{R} \$ 449$ mil $\left.^{21}\right)$, com grande população, apresentavam menor participação do valor e níveis de preços médios, como verificado pelo caso do MSP (preço médio de $\mathrm{R} \$ 357 \mathrm{mil}$ ).

As informações do CIF (2016), utilizado para o lançamento do IPTU, mesmo carecendo de reparos e detalhes, permite esclarecer uma parte importante da lacuna de conhecimento sobre a cidade, tais como, até 2015: haviam 3,28 milhôes de proprietários, divididos em contribuintes de tributo total (15,5\%), com descontos (84\%), isentos (cerca de 3,2\% estimado pelo CIF de 2018, acessado pela Lei de Acesso a Informação - $\left.(\mathrm{LAI})^{22}\right)$ e imunes $(0,5 \%)$. De acordo com a Consolidação das Leis Tributárias (CLT, 2015), é possível estimar os grupos de contribuições e as suas características. Com essas considerações, elaboramos estimativas dos Estoques de Imóveis Tributados (ET) (excluídos imóveis imunes e isençóes) e das Contribuiçóes Totais (CT) comparadas às Contribuiçôes Efetivas (CE) arrecadadas pelo IPTU.

Tabela 8. Estrutura de Contribuintes do MSP, por conjunto de Propriedades Cadastradas (PC), Contribuintes Pagantes (CP), com Desconto e Náo Pagantes, por valor em R \$ milhóes dos Estoques de Imóveis Tributado (ET), da Contribuição Total (CT) e Efetiva (CE), e as razóes de participação relativa, no MSP entre 2000 e 2015

\begin{tabular}{lrrrr}
\hline \multicolumn{1}{c}{ Unidades } & $\mathbf{2 0 0 0}$ & \multicolumn{1}{c}{$\mathbf{2 0 0 5}$} & \multicolumn{1}{c}{$\mathbf{2 0 1 0}$} & \multicolumn{1}{c}{$\mathbf{2 0 1 5}$} \\
\hline Propriedade Cadastradas (PC) & 2.434 .790 & 2.727 .575 & 2.962 .129 & 3.280 .733 \\
Tributo Completo & 371.809 & 407.232 & 458.274 & 508.544 \\
Tributo com Desconto & 2.055 .810 & 2.310 .065 & 2.496 .655 & 2.755 .480 \\
Imunes & 7.171 & 10.278 & 7.200 & 16.709 \\
\hline \multicolumn{1}{c}{$\mathbf{R} \mathbf{\$}$ Milhões } & $\mathbf{2 0 0 0}$ & $\mathbf{2 0 0 5}$ & $\mathbf{2 0 1 0}$ & $\mathbf{2 0 1 5}$ \\
\hline Estoque Tributado (ET) & $\mathbf{6 3 9 . 2 3 5}$ & $\mathbf{7 1 2 . 8 9 1}$ & $\mathbf{7 9 4 . 5 5 0}$ & $\mathbf{9 0 1 . 1 7 7}$ \\
\hline Contribuição Total (CT) & 8.862 & 9.942 & 11.121 & 12.636 \\
Contrbuição Efetiva (CE) & 4.160 & 4.129 & 5.568 & \multicolumn{1}{c}{6.543} \\
\hline Participação relativa & $\mathbf{2 0 0 0}$ & $\mathbf{2 0 0 5}$ & $\mathbf{2 0 1 0}$ & $\mathbf{2 0 1 5}$ \\
\hline CE/ET & $0,65 \%$ & $0,58 \%$ & $0,70 \%$ & $0,73 \%$ \\
CT/ET & $1,39 \%$ & $1,39 \%$ & $1,40 \%$ & $1,40 \%$ \\
\hline
\end{tabular}

Fonte: PMSP, Dados Abertos. Disponível em: <http://dados.prefeitura.sp.gov.br/pt_PT/>. Acesso em dez. 2017. PMSP/Fazenda/Contas Públicas/Receitas Arrecadas (2005 a 2015). Disponível em: <http://www.prefeitura.sp.gov.br/cidade/secretarias/fazenda/contaspublicas/index.php?p=3216>. Acesso em abr. 2018; Receitas Arrecadas (2000), F. Seade e Demonstrativos Gerais do Município PMSP 2015. Elaboração própria. * Reajustado pelo IGP-DI, disponível no Ipeadata, ao nível de preço de 2015. 
Uma tendência importante pode ser percebida pela relação do valor da contribuição total (IPTU total estimado), com o valor do estoque imobiliário tributado (CT/ET), de 1,40\% em 2015, que está longe da contribuição efetiva (arrecadação do IPTU) sobre estoque tributado (CE/ET), que era de $0,73 \%$. Se entendermos a inadimplência pela diferença entre a contribuição total e a efetiva, essa diferença era maior (53,1\%) nos anos 2000, e chega a pouco menos da metade (49,2\%) em 2015. Em 2000, a distância da contribuição total (projetada de 1,39\%) para a efetiva (recebida de $0,65 \%$ ) era ainda maior na sua relação com o estoque tributado. Piora depois, em 2005 (1,39 e 0,58\%), evoluindo com o crescimento da contribuição efetiva em $2010(0,70 \%)$. Essa nova tendência é importante, tendo em vista o histórico de inadimplência e de importância da dívida tributária no Balanço Patrimonial do $\mathrm{MSP}^{23}$.

Isso se relaciona também com a alteração da institucionalidade, que ocorreu em 2005, por consequência da Lei municipal n. 14.107, que dispôs sobre o processo administrativo fiscal e o Conselho Municipal de Tributos. Com isso, o inspetor fiscal recebeu maior legitimidade, por meio do conjunto de normas para a sua atuação e formalização do crédito tributário. $\mathrm{O}$ processo administrativo fiscal ganhou um órgão competente que acompanha o ato de infração, seja no processo fiscal ou após a solicitação de impugnação de exigência fiscal de contribuinte, na primeira instância no âmbito de órgão da Receita Municipal. O litígio pode seguir ainda numa segunda instância no âmbito do Conselho Municipal de Tributos, formado por membros indicados do setor público e privado (entidades) e nomeados pelo prefeito ${ }^{24}$.

Além disso, a Lei municipal n. 15.044/2009 estipulou a obrigatoriedade de o Poder Executivo encaminhar, ao Poder Legislativo, projeto de lei com proposta de atualização dos valores dos preços unitários do metro quadrado da construçâo e do terreno, a ser realizada a cada mandato. Isso, que deveria ter sido realizado em 2013, tardaria devido à dificuldade de transparência, debate e negociação do reajuste. Sem isso, por conta da tradição histórica de influência política de poucos grupos sobre o Estado, mesmo após a promulgação da lei que regula o reajuste sistemático dos preços dos imóveis, a revisão da PGV provocaria enorme alvoroço no meio midiático. $\mathrm{Na}$ justiça comum, as entidades (patronais e de proprietários) saíram em defesa dos direitos dos consumidores e da "razoabilidade" do reajuste do imposto, o que acabou por se mostrar além de razoável, legal e legítimo no âmbito dos três poderes do Estado em 2015.

\section{ASSOCIAÇÕES E INTERESSES SOCIAIS E DOS EMPRESÁRIOS}

O reajuste dos preços da Planta Genérica de Valores (PGV), que embasa o Valor Venal do Imóvel (VVI) para a cobrança do IPTU, que passa por meio da aprovaçáo da Câmara de Vereadores, provoca grande alvoroço, inclusive com disputas no âmbito da justiça comum. Nesses momentos, evidenciam-se quais são as entidades interessadas, especialmente na redução do imposto. A defesa contrária à contribuição do tributo encobre os interesses de grandes proprietários, que não querem revelar tanto os preços subavaliados como a respectiva subcontribuição à arrecadação do fisco municipal e, como se observa no dia a dia da cidade, faz falta ao incompleto sistema de equipamentos públicas e sociais do MSP25.

A Federação das Indústrias do Estado de São Paulo (FIESP) (de 1931) e o Centro das Indístrias do Estado de São Paulo (CIESP) (criado em 1928) disputaram, ao longo
23 Disponível em 26/03/2018: http://www. prefeitura.sp.gov.br/cidade/ upload/01-05-BG2015Consolidado-Balanco-Patrimonial_1459430842.pdf.

24 Entretanto, o Artigo 64 da CLT do MSP (2015) possibilita ao contribuinte um forte poder de resistência, por meio da impugnação da base de cálculo aplicada pela lei, por meio de avaliação contraditória a SMFDE/SMF. Como nos contou em entrevista, a professora Ursula D. Peres da USP: "Isso leva ao movimento de inadimplência dos mais ricos, visando Leis de Anistia e de Renúncia Fiscal, diretamente negociada com a Prefeitura. De outro lado, os inadimplentes mais pobres buscam acessar a Leis Municipais de Anistia e Renúncia, mas por meio dos vereadores, de acordo com os territórios e as bases eleitorais".

25 Fato constato em pesquisa anterior (BORGES, 2016). 
26 Ver em: "Skaf tem empresas de imóveis com interesses privados no engessamento do IPTU" (Rede Brasil Atual 23/12/2013).

27 Dados dispersos indicam que participam do CMVI: Sindicato da Indústria da Construção Civil do Estado de São Paulo (SindusCon-SP), Câmara Municipal, Departamento Intersindical de Estatística e Estudos Econômicos (DIEESE) Conselho Regional de Corretores de Imóveis (CRECI) e o Sindicato das Empresas de Compra, Venda, Locação e Administração de Imóveis Residenciais e Comerciais de São Paulo (Secovi-SP).

28 De acordo com Cano (2011, p. 14): A dominação mercantil, que vem do antigo mundo rural, colonial e escravocrata, travestiuse como capital imobiliário que se expande no século $X X$, dirige a especulação da propriedade nas cidades.

29 Como se observa na perspectiva de Fernandes (1975, p. 204): A preservação da "burguesia" numa economia dependente e subdesenvolvida constróise pelo controle do Estado da estrutura da terra, da riqueza, do poder político e dos privilégios. de todo o ano de 2014, na mídia e na justiça comum, o reajuste do IPTU, como o aspecto mais notado da política fiscal do MSP, que, junto ao impostômetro da Associação Comercial de São Paulo (ACSP) (de 1894), constitui uma campanha irrestrita contra impostos em geral. Destaca-se o fato de que, para o enfretamento do reajuste do IPTU, as entidades terem argumentado em defesa dos consumidores, sem considerar a lei de reajuste do tributo, o custo de produção ou mesmo qualquer estratégia que envolva uma proposta de desenvolvimento do setor ou da cidade.

$\mathrm{Na}$ visão dessas entidades e seus representantes, com relação à lei municipal de revisão do imposto, "Não é possível aceitar esse reajuste desproporcional", afirmou o presidente da Fiesp, Paulo Skaf, pois "ainda que fosse razoável o aumento do valor dos imóveis, a renda do cidadáo não subiu na mesma proporção" (FIESP-Notícias, 16/01/2014). No entanto, enquanto os preços subiram, e alguns proprietários ganharam fortunas ${ }^{26}$, muitos outros cidadãos sofreram as consequências da dificuldade de aluguel, de compra do imóvel e de moradia cada vez mais distante, mesmo com amplos estoques existentes de imóveis construídos e terra para a construção nas áreas centrais. Por isso, "é desanimador que uma iniciativa tão patrimonialista como a ação contra o IPTU paulistano tenha vindo justamente da representação de classe dos industriais da maior economia estadual brasileira” (GGN, 18/12/2014).

Outros interesses corporativos, patrimoniais e espaços de disputa da política fiscal podem ser evidenciados nas informaçóes de mídias, que se revela como um campo de atuação de diferentes grupos. Os grandes grupos da mídia, caso da Rede Bandeirantes, que abrange emissoras de sinal aberto, a cabo, rádios e materiais impressos, detém ainda a propriedade de muitos imóveis urbanos na cidade, o que compóe o poder econômico do seu principal acionista, e por isso se interessam pelo debate do reajuste do IPTU no MSP. Isso explica a reação desse grupo (Rede Bandeirantes), entre outros, sobre o recente reajuste e progressividade da receita do IPTU, como registra o blog Conversa Afiada ("Saad da Bandeirantes ameaçou Haddad", 17/12/2013). A concentraçáo de interesses privados e midiáticos associados ao patrimônio imobiliário articula interesses de proprietários de toda ordem, na influência mercantil para o enfraquecimento da política tributária, necessária à "valorização" dos ativos imobiliários. Por sua vez, os pequenos grupos de mídias alternativas ao oligopólio do setor de comunicação, nas franjas da rede de informação, contam os bastidores da história dos interesses de grandes proprietários e de sua aversão fiscal.

Nos diferentes mandatos do governo local, uma arena de disputa relevante está nas reuniōes do Conselho Municipal de Valores Imobiliários (CMVI), composta por servidores públicos, convocados por diretores ou prefeito. Nela, elabora-se a proposta de Valores Venais dos Imóveis (VVI), a base para aferição do IPTU, apreciada pelo executivo e legislativo, porém sem dados ou relatórios públicos sobre a composição do conselho, seu planejamento e suas decisôes. As informaçôes utilizadas neste estudo foram levantadas não de relatórios, mas de apresentaçóes eventuais, datadas do reajuste da $\mathrm{PGV}^{27}$.

O histórico caráter mercantil ${ }^{28}$, patrimonialista e concentrador da renda, riqueza e do mercado imobiliário brasileiro ${ }^{29}$, como se vê no caso paulistano, resulta tanto na dificuldade do acesso regular à moradia, como na falta de renda relativa ao preço da terra, que implica a expansão da ocupação irregular (favelas e cortiços) e, com isso, uma enorme diferenciação no acesso aos direitos, assim como uma dificuldade de universalização das políticas públicas. Com esse desenvolvimento social desigual 
e heterogêneo, surgiram movimentos de associaçôes locais, grupos técnicos e de burocratas em apoio à extensão das condiçôes de cidadania e direitos a moradia regular, transporte, água, luz e serviços públicos constituindo a Agenda da Reforma Urbana, que esbarra numa antiga falta de vontade política e financeira ${ }^{30}$.

O desenvolvimento da Agenda de Reforma Urbana nas décadas posteriores aos anos 1960, interrompido pelo regime militar, revigorou-se com o movimento democrático, com algum apoio na Constituição de 1988, que garantiria a função social da propriedade, e depois com o Estatuto da Cidade em 2001, que criaria as condiçôes para regulaçáo da progressividade do IPTU. Isto se tornaria, em tese, um suporte legal ao aumento da carga tributária, mas tem enfrentado uma tremenda resistência política, jurídica e cultural.

Recentemente, junto à organização da luta por terra no campo, originou-se o Movimento dos Trabalhadores Sem Teto (MTST), entre outros movimentos urbanos, que se destacam na luta por moradia, com intuito de ampliar o acesso à terra urbana. Como estaca Guilherme Boulos, uma das lideranças do MTST, a garantia de moradia digna enquanto "direito fundamental", como prevê a Constituição, além das ocupações como "expressões de resistência" são necessários instrumentos, como o IPTU progressivo e a lei do inquilinato, regulando reajustes de aluguel, como acontece nos Estados Unidos (em Nova Iorque) e Europa ${ }^{31}$.

Entre outras instituiçôes defensoras do projeto da Reforma Urbana no Brasil e importante no MSP, destaca-se o Instituto Polis, criado em 1987 para a defesa de cidades mais justas. Entre os valores defendidos pelo Instituto estão os instrumentos de IPTU Progressivo no Tempo, para imóveis que não cumpram a função social, regularização das moradias populares em situação de irregularidade jurídica-urbanística e desenvolvimento social, cultural e ambiental.

A demanda por políticas públicas, descentralização e participação, por necessidade de recursos para a sua realização, passa pela política sobre a propriedade, imposto e usos dos imóveis. Em entrevista, a professora Ursula D. Peres $(29 / 03 / 2018)^{32}$, destaca, como limites concretos à participação, debate e planejamento das políticas públicas nas regiôes da cidade: a quantidade de recursos vinculados, fechados ao debate; a redução do IPTU como forma de financiamento da receita própria; e mesmo o aumento da dívida pública existente, como frisado por Oliveira (2012). Ainda assim, o movimento da Rede Nossa Sáo Paulo, que atua desde 2007, conseguiu algum sucesso na iniciativa de processos participativos, com auxílio do envolvimento dos poderes legislativo e executivo, no que diz respeito à participação no planejamento e na avaliação de metas setoriais e regionais. No entanto, fê-lo com o planejamento restrito à despesa, sem envolver ainda a discussáo sobre a origem da receita e, mesmo, o IPTU.

A limitada capacidade de apoio do IPTU ao financiamento do governo do MSP tem avançado pouco diante dos problemas da cidade. $\mathrm{O}$ jogo de desinformação da mídia oligopolista, assim como a falta de transparência e de prestação de contas públicas fortalecem a resistência interna e externa ao governo local no processo de institucionalização cidadá do imposto, no sentido de ser progressiva, clara e negociada. Assim, o aumento do IPTU para o reforço da autonomia das políticas fiscal e territorial do governo municipal mostra-se um desafio colossal que se coloca à burocracia do Estado, no espaço legislativo e judiciário, e para parcelas interessadas da sociedade civil, as quais, em busca de uma política mais inclusiva de direitos, enfrentam a resistência patrimonial da dinâmica capitalista imobiliária mercantil de longa trajetória
30 Como destaca Leal (1997, p. 66-78), a preservação da fraqueza política, econômica e financeira do município no surgimento da República, sob a dependência dos demais níveis de governo, manteve suscetíveis os compromissos de apoio político e eleitoral, do uso do poder físico, para a concentração do poder político e da riqueza, reproduzindo a miséria social.

31 Ver em: "Coordenador do MTST dá aula pública no centro de SP" (GGN 13/12/2014).

32 Ursula Dias Peres é Administradora Pública, Mestre e Doutora pela FGV, Professora da EACH/USP. Atuou na Secretaria de Finanças (2002-2003) e como Secretária Adjunta de Planejamento, Orçamento e Gestão no MSP (2013). 
histórica, defendida por poderosos interesses - FIESP, CIESP e grande mídia - institucionalizados, corporativos e sem projetos de sociedade, de direitos ou de nação.

\section{CONSIDERAÇÕES FINAIS}

Como percebemos através da política fiscal e urbana das cidades, tanto pela substância e estratégia da arrecadação, como pela forma de organização e de limites financeiros da oferta de infraestrutura básica, fica evidente a relação de interesses do mercado imobiliário e da resistência por direitos que compóe as coalizóes dentro da política pública, fiscal e urbana. As coalizóes de resistências ao ISP, organizadas por diferentes estratégias nos países, regiōes e locais, voltam-se a interesses específicos: em Nova Iorque, mais preocupados com as condições da produçáo, renovação e verticalização, para a "revalorização" ampliada de ativos; em São Paulo, engajada na defesa do oportuno ganho mercantil, por meio da retenção da propriedade para inflação do preço e extração de renda absoluta - como denuncia a importância dos terrenos, garagens e estacionamentos no CIF (2016), mais relevantes em área, do que no preço avaliado ou contribuição ao IPTU.

$\mathrm{Na}$ NYC, a maior capacidade fiscal da cidade historicamente possibilitou uma infraestrutura e serviços públicos mais completos, também associados com a especulação imobiliária, mas em escala industrial no universo da metrópole, ainda que com a diferenciação, segregação e expulsão de parte da população pobre. No MSP, a estratégia dos interesses imobiliários passa pela relação entre uma baixa contribuiçáo do ISP, incapacidade fiscal e a escassez de infraestrutura e serviços públicos, ainda que sob substancial "valorização" dos preços, sustentada por uma extrema diferenciação de classes e espaços sociais.

O sistema de ISP, como consideram De Cesare e Smolka (2004, p. 5), tem cer-

33 Dados do Censo de de 3,5 milhões de domicílios, postos ao lado dos de proprietários de Residências do CIF-MSP, de 2,5 milhões imóveis, expressam a dificuldade da habitação regular na cidade, maior nas periferias onde os domicílios superavam os imóveis residenciais, enquanto nas regiões mais ricas e centrais concentravam mais contribuintes de residências do que domicílios do IBGE, indicando a relevância de imóveis vagos. Um fato importante é que essa diferença de domicílios do Censo em relação aos residenciais do CIF tem aumentado de 933.670, em 2000, para 1.072.069, em 2010. Sem considerar os domicílios em favelas 386.483, conhecidos em 2010 , junto a outros usos, desconsiderado pelo CIF. Esses dados indicam a baixa cobertura do CIF do MSP, que pode chegar a 1,5 milhão de imóveis. tos aspectos críticos para o desempenho do tributo, que nos ajudam a estabelecer as diferenças entre as políticas fiscais das cidades: Instituição da Alíquota, Cobertura do Cadastro, Avaliação do Estoque e Eficiência da Arrecadação. Por sua vez, na NYC esses aspectos são mais completos e disponibilizados, com algum histórico, por meio de relatórios, cartilhas e bases de dados, no MSP a disponibilidade da base de dados é recente, não há cartilhas ou relatórios que ajudem a entender a importância do CIF para o conhecimento da cidade e do mercado imobiliário ou que apoie o debate e o planejamento da política pública, fiscal e urbana. Além disso, a sua cobertura ${ }^{33}$, a avaliação de estoque e a eficiência da receita são ainda bastante deficientes.

Entretanto, nos momentos de reajuste de valores tributáveis, em ciclos avaliatórios (DE CESARE e SMOLKA, 2004, p. 8), vê-se a tensão que a possibilidade de "elevação" do IPTU causa nos interesses patrimonialistas, como destacado pelas entidades paulistanas (FIESP, CIESP, ACSP e Rede Bandeirantes). Longe de argumentar sobre a estratégia de desenvolvimento da produção imobiliária ou da política urbana, como fazem os correlatos na NYC, utilizam a defesa dos direitos de consumidores, quando se trata da defesa da posição especulativa da propriedade de imóveis como mero ativo. Colocam, assim, os interesses de proprietários acima e na contramáo das legislaçôes de âmbito federal e local. Por outro lado, é da luta de movimentos sociais por acesso a direitos na cidade (reforma urbana) que têm-se obtido conquistas importantes como: a aplicação da função social da propriedade, a atualização dos tributos, 
a abertura do CIF e a progressividade da receita de IPTU no MSP, ainda que lenta.

$\mathrm{O}$ distinto resultado em termos de alíquotas médias de fato tributadas pelos governos (na forma da razão do ISP relacionada ao valor estimado do estoque imobiliário, que em 2015 era de 2,48\% NYC e 0,73\% MSP), tem raízes profundas e constituise em um diferencial estrutural importante de recursos próprios disponíveis para as políticas públicas, como de aquisição de terras para equipamentos, custeio de pessoal e desestímulo à especulação. A novidade é o recente, ainda que leve, aumento do ISP arrecadado em ambas as cidades, após um período de intensa pressão para a sua isenção. O aumento do interesse por reforma urbana e planejamento comunitário, como consequência dos excessos da falta de regulamentação dos mercados (em benefícios das finanças e especulação imobiliária), ajuda a entender, no período analisado, essa leve retomada do ISP em ambas as cidades.

Uma conclusão importante é de que o maior nível do imposto sobre a propriedade (como verificado na NYC) náo inviabiliza a capital do mercado imobiliário, como a denomina Angotti (2008). Assim como uma baixa tributação (observada no MSP) não favorece o desenvolvimento do mercado, e principalmente, prejudica a universalização das políticas públicas, fiscais e urbanas (BORGES, 2016), além de estimular a "valorização" extraordinária da riqueza, pela desoneração da propriedade da terra. Por isso, o desenvolvimento institucional da política fiscal, como observado no caso do ISP, sob o aspecto da construção de sua legitimidade, por meio da produção de dados e análises dos impostos arrecadados e dos impactos das políticas locais, mostrase fundamental para o diálogo, educação e negociação fiscal das políticas públicas, tendo em vista a formulação de planos de ação pública progressiva e de longo prazo.

Mesmo que a participação social no Brasil tenha aumentado, as decisões importantes sobre as estratégias de desenvolvimento local ainda se mantêm muitas vezes restritas ao governo e influenciadas por poucos. Tal pode-se constatar no caso do IPTU em São Paulo, que tem avançado, mas com muito a percorrer na abertura do debate, das informaçóes cotidianas, e sobre perspectivas e alternativas. Esse caminho institucional parece ser sem volta e estar em movimento nos dois sistemas fiscais, de planejamento e de políticas investigadas, com diferentes níveis de avanços, limites e com retrocessos no processo de gestão da política.

\section{REFERÊNCIAS BIBLIOGRÁFICAS}

ANGOTTI, Tom. New York for Sale: community planning confronts global real estate. Cambridge (MA): The MIT Press, 2008.

BACHUR, João Paulo. Federalismo Fiscal, atribuições constitucionais e equalização regional: EUA, Alemanha e Brasil em perspectiva comparada. Revista do Serviço Público. Brasília, N. 56 Out/Dez 2005.

BORGES, Luís Maurício Martins Borges. Investigação: integração da política fiscal orientada à universalização do direito à cidade. In: BALBIN, Renato; KRAUSE, Cleandro. Eixos da Estruturação da Transformação Urbana. Rio de Janeiro: Ipea, 2016. Disponível em: <http://www.ipea.gov.br/portal/index.php?option=com_content\&view=article\&id $=28493>$.

CANO, Wilson. Ensaios sobre a crise urbana do Brasil. Campinas (SP): Ed. Unicamp 2011.DE CESARE, Claudia; SMOLKA, Martin. Diagnóstico sobre o IPTU. Cambridge (MA): Lincoln Institute of Policy Land, 2004.

\begin{abstract}
Luís Maurício Martins Borges é economista graduado na Universidade Federal do Paraná, mestre e doutorando no Instituto de Economia da Universidade Estadual de Campinas em Desenvolvimento Econômico na linha espaço e meio ambiente. Professor do Curso de Ciências Econômicas da Faculdade de Economia (FAECO), do Centro Universitário Fundação Santo André (CUFSA).

Email:luismmborges@yahoo. com.breluis.borges@fsa.br ORCID: http://orcid.org/00000001-8013-0208

Artigo recebido em 16 de outubro de 2017 e aprovado para publicação em 07 de julho de 2018.

Artigo licenciado sob Licença Creative Commons (CC-BY).
\end{abstract}


DI PASQUALE, Denise; WHEATON, William C. Urban Economics and Real State. New Jersey: Prentice Hall, 1996.

FERNANDES, Florestan. A revolução burguesa no Brasil: ensaio de interpretação sociológica. São Paulo: Zahar, 1975.

LOGAN, John R.; MOLOTCH, Harvey L. Urban Fortunes, the Political Economy of Place. Berkeley (CA): University of California Press, 1987.

LEAL, Victor Nunes. Coronelismo, enxada e voto. Rio de Janeiro: Nova Fronteira, 1997.

MOLOTCH, Harvey. The city as a growth machine: toward a political economy of place. The American Journal of Sociology. Vol. 82 (2), p. 309-332, 1976.

MOODY, Kim. From Wellfare State to Real Estate. Editora The New Press, NY 2007.

OLIVEIRA, Fabrício Augusto; BIASOTO JÚNIOR, Geraldo. A reforma tributária: removendo entraves para o crescimento, a inclusão social e o fortalecimento da federação. Texto para Discussão. Unicamp: Instituto de Economia, 2015.

OLIVEIRA, Rogério Ceron. Evolução das finanças municipais: o caso da Cidade de São Paulo: 1995 a 2010. 2012. Dissertação de Mestrado - Instituto de Economia, Universidade Estadual de Campinas, Campinas (SP), 2012.

STONE, Clarence. Urban regimes and the capacity to govern: a political economy approach. Journal of Urban Affairs, Volume 15, Number 1, pages 1-28, 1993.

ZUKIN, Sharon. Naked City, the death and life of authentic urban places. Oxford University Press, NY 2010. 